Société d'histoire de la révolution de 1848 et des

révolutions du XIXe siècle

16 | 1998

1848. Un modèle politique à l'épreuve

\title{
1848 et la Seconde République : 50 années de recherches. Bibliographie, 1948-1997 (suite)
}

Jean-Luc Mayaud

\section{(Q) OpenEdition \\ Journals}

Electronic version

URL: http://journals.openedition.org/rh19/135

DOI: $10.4000 /$ rh 19.135

ISSN: $1777-5329$

\section{Publisher}

La Société de 1848

\section{Printed version}

Date of publication: 1 June 1998

ISSN: 1265-1354

Electronic reference

Jean-Luc Mayaud, «1848 et la Seconde République : 50 années de recherches. Bibliographie,

1948-1997 (suite) », Revue d'histoire du XIXe siècle [Online], 16 | 1998, Online since 10 September 2008 connection on 21 April 2019. URL : http://journals.openedition.org/rh19/135; DOI : 10.4000/rh19.135

This text was automatically generated on 21 April 2019

Tous droits réservés 
1848 et la Seconde République : 50 années de recherches. Bibliographie, 1948-1997 (suite)

Jean-Luc Mayaud

INDEX

Mots-clés: 1848, Bibliographie, Historiographie, Seconde République 